\title{
A new combinational statistical approach for cellulase optimization in Aspergillus nidulans
}

\author{
S. Anuradha Jabasingh ${ }^{1}$ and C. Valli Nachiyar ${ }^{2}$ \\ ${ }^{1}$ Dept. of Chemical Engineering, ${ }^{2}$ Dept. of Biotechnology, Sathyabama University, Chennai-600119, India \\ anu3480@yahoo.com
}

\begin{abstract}
The enhancement of the cellulase activity of Aspergillus nidulans by combinational optimization technique was investigated. The strain isolated from decayed, dry leaf of Ficus caricus was compared for the first time for its ability to produce cellulolytic enzyme in submerged fermentation $(\mathrm{SmF})$. The medium ingredients enhancing the cellulase production were optimized by combinational statistical approach by one factor at a time methodology (OFAT), Plackett Burmann methodology (PB) and response surface methodology (RSM). A four-factor-five-level central composite design (CCD) was employed to determine the maximum activity of cellulase at optimum levels of carboxy methyl cellulose $(\mathrm{CMC})$, ammonium nitrate and potassium dihydrogen phosphate at varying $\mathrm{pH}$ values. The optimum fermentation parameters were found to be $1.2 \mathrm{~g} / \mathrm{l} \mathrm{CMC}, 0.9 \mathrm{mg} / \mathrm{l}$ ammonium nitrate and $0.75 \mathrm{mg} / \mathrm{l}$ potassium dihydrogen phosphate at $\mathrm{pH}$. The optimization of medium by combinational statistical approach led to the fine tuning of the cellulase production thereby enhancing the cellulase activity from $4.91 \mathrm{U} / \mathrm{ml}$ to $39.56 \mathrm{U} / \mathrm{ml}$. The predicted results were in agreement with the actual experimental values. The cellulase activity obtained with this strain may be one of the best obtained in Aspergillus nidulans.
\end{abstract}

Keywords: Aspergillus nidulans, cellulase activity, submerged fermentation, response surface methodology

\section{Introduction}

In recent years, more attention is given to the process of cellulose biodegradation to soluble sugar (Chen et al., 2008). Cellulase production in fungi is found to be extracellular and has three components such as endoglucanase, exoglucanase and $\beta$-glucosidases (Breznak \& Brune, 1994; Yi et al., 1999). Until now cellulolytic enzymes have been isolated from bacteria and fungi (Tomme et al., 1995), plants (Brummell et al., 1994), molds (Blume \& Ennis, 1991), microbes from animal intestines (Moriya et al., 1998) and herbivorous invertebrates such as arthropods (Watanabe et al., 1997; Tokuda et al., 1997; Watanabe et al., 1998), nematodes (Smant et al., 1998) and mollusks (Yokoe \& Yasumasu, 1964).

A number of microorganisms particularly fungi possessing cellulose degrading enzymes have been isolated and studied extensively (Kim et al., 2003). Cellulases are inducible enzymes which are synthesized by microorganisms during their growth on cellulosic materials (Lee \& Koo, 2001). They are studied extensively due to their application in the hydrolysis of cellulose, the most abundant biopolymer and potential source of utilizable sugars, which serves as a raw material in the production of chemicals and fuel. Cellulases have a wide range of industrial applications. The main applications include textile, paper and pulp, food, animal feed, fuel and chemical industry. Additionally they can be used in waste management, pharmaceutical industry, protoplast production and genetic engineering
(Bhat, 2001). However, not many studies are available on the fungi Aspergillus nidulans to exploit its potential in the production of cellulase. In the present study, one factor at a time methodology (OFAT) (Skowronek \& Fiedurek, 2004), Plackett Burmann methodology (PB) (Berekaa et al., 2006) and response surface methodology (RSM) (Amani et al., 2007) have been adopted to optimize the medium requirements for the production of cellulase by $A$. nidulans. The central composite design (Guangrong et al., 2008) was used to optimize the levels of identified controllable factors affecting the medium.

\section{Materials and methods \\ Microorganism, medium and culture conditions}

Aspergillus nidulans isolated from decayed, dry leaf of Ficus caricus in the laboratory was maintained on agar slants at $4^{\circ} \mathrm{C}$ and sub cultured every 4 weeks. The initial medium (IM) components chosen were CMC, cellulose, sucrose, glucose, yeast extract, ammonium nitrate, peptone, urea, calcium chloride, potassium dihydrogen phosphate, manganese sulphate. $\mathrm{H}_{2} \mathrm{O}$ and thiamine hydrochloride. $0.005 \mathrm{mg}$ of streptomycin was added to prevent bacterial growth during incubation. The $\mathrm{pH}$ of medium employed for the studies was $3,4,5,6$ and 7 . $A$. nidulans was grown in shake flask under submerged fermentation (SF) conditions with IM in order to examine the effect of incubation time on cellulase activity and dry cell weight of the fungus. After $8 \mathrm{~d}$ of incubation at $30^{\circ} \mathrm{C}$, the culture broth was filtered through glass fiber filter paper (Whatman GF/C) to remove hyphal fragments and residual insoluble cellulose. The culture filtrate was freeze 
dried and resuspended in $100 \mathrm{ml}$ of $0.05 \mathrm{M}$ citrate buffer ( $\mathrm{pH} 4.8)$. The mixture was stirred overnight and insoluble material was removed by centrifugation (40 min. at 5000 g). Cellulases were then assayed.

\section{Materials}

CMC and Cellulose were procured from Sigma chemicals (Mumbai, India). Agar and other medium components were purchased from Hi-media (Mumbai, India). All other analytical grade reagents were supplied by Merck (Mumbai, India) and SD Fine chemicals (Mumbai, India).

\section{Enzyme assay}

Gel diffusion assay (Saczi \& Radford, 1986) was performed to assess the magnitude of the cellulase activity. Assay for endo beta-1, 4 glucanase, exo beta-1, 4 glucanase and $\beta$-glucosidase was carried out by carboxy methyl cellulose (CMC) assay, filter paper (FP) assay and cellobiase assay according to IUPAC recommendation (Ghose, 1987). One unit of CMC activity was defined as the amount of enzyme needed to liberate one $\mu \mathrm{mol}$ of glucose/min. from $1 \mathrm{ml}$ of culture broth under assay conditions during the hydrolysis of CMC. One unit of FP degrading activity was defined as the amount of enzyme needed to liberate $1 \mu \mathrm{mol}$ of glucose/min. during hydrolysis of $50 \mathrm{mg}$ of Whatman filter paper. One unit of cellobiase activity was defined as the amount of enzyme needed to liberate $2 \mu \mathrm{mol}$ of glucose $/ \mathrm{min}$. during hydrolysis of cellobiose. Glucose in the culture supernatant was analyzed by using UV Visible spectrophotometer (Hitachi Model-100-40) at $540 \mathrm{~nm}$.

\section{One factor at a time methodology (OFAT)}

In the medium selected, glucose, sucrose, CMC and cellulose were substituted as four different carbon sources. All carbon sources were used at $2 \%(\mathrm{w} / \mathrm{v})$ concentration. The effect of different nitrogen sources on cellulase production was studied by employing yeast extract, peptone, urea and ammonium nitrate at $0.5 \%$ $(w / v)$ concentration. To study the effect of mineral salts on cellulase production, calcium chloride, potassium dihydrogen phosphate, manganese sulphate. $\mathrm{H}_{2} \mathrm{O}$ and thiamine hydrochloride were employed at $0.5 \mathrm{mg} / \mathrm{l}$ concentration. The fermentation experiments were carried out at initial pH values varying between 3 and 7 .

Table 1. Medium components for screening using $P B$ design

\begin{tabular}{|c|c|c|c|}
\hline \multirow{2}{*}{ Variables } & \multirow{2}{*}{ Medium component } & \multicolumn{2}{|c|}{ Levels } \\
\cline { 3 - 4 } & & $\mathrm{L}(-1)$ & $\mathrm{H}(+1)$ \\
\hline$A$ & $\mathrm{KH}_{2} \mathrm{PO}_{4}(\mathrm{mg} / \mathrm{l})$ & 0.25 & 0.75 \\
\hline$B$ & Urea $(\mathrm{mg} / \mathrm{l})$ & 0.3 & 0.5 \\
\hline$C$ & $\mathrm{NH}_{4} \mathrm{NO}_{3}(\mathrm{mg} / \mathrm{l})$ & 0.3 & 1.5 \\
\hline$D$ & $\mathrm{MnSO}_{4} . \mathrm{H}_{2} \mathrm{O}(\mathrm{mg} / \mathrm{l})$ & 0.1 & 0.1 \\
\hline$E$ & Thiamine $\mathrm{HCl}(\mathrm{mg} / \mathrm{l})_{1}$ & 0.01 & 0.01 \\
\hline$F$ & Peptone $(\mathrm{mg} / \mathrm{l})$ & 0.1 & 5.0 \\
\hline$G$ & $\mathrm{CMC}(\mathrm{g} / \mathrm{l})$ & 0.2 & 2.0 \\
\hline
\end{tabular}

\section{Plackett Burmann screening design (PBSD)}

Plackett Burmann screening design (PBSD) was used to screen ( $n)$ variables in just $(n+1)$ number of experiments (Plackett \& Burman, 1946; Ghanem et al., 2000 ) resulting in a tremendous decrease in the number of total experiments. PBSD was employed to evaluate the relative importance of various components in promoting cellulase activity and to screen the important variables affecting the cellulase production. The preliminary information for the trails was taken from the results of OFAT trails. The PBSD was set up for 7 variables in 2 levels, high and low. The high level of each variable was set far enough from low level to identify the ingredients of the media having significant influence on cellulase production. The PBSD matrix was developed using SAS package version 8.01. The medium components used in the PBSD trials are shown in Table 1.

\section{Central composite design (CCD)}

After optimizing the values of medium components by OFAT and PBSD 4 most important variables namely, $\mathrm{CMC}$ at $2 \mathrm{mg} / \mathrm{l}$, ammonium nitrate at $0.3 \mathrm{mg} / \mathrm{l}$ and 1.5 $\mathrm{mg} / \mathrm{l}$, potassium dihydrogen phosphate at $0.75 \mathrm{mg} / \mathrm{l}$ and $\mathrm{pH}$ at 5 were observed to mainly control the cellulase production by $A$. nidulans under $\mathrm{SmF}$ conditions. Based on the results from PBSD, CMC, ammonium nitrate, potassium dihydrogen phosphate and $\mathrm{pH}$ were selected for further evaluation of their effects on cellulase activity by $C C D$, a very useful tool for determining optimal level and interaction of medium constituents. RSM consists of a group of empirical techniques devoted to the evaluation of existing relation between a cluster of controlled experimental factors and the measured responses according to 1 or more selected criteria. A prior knowledge and understanding of the process as well the process variables under investigation are necessary for achieving a more realistic model. For RSM analysis based on CCD, 30 experiments were performed in triplicate. The coded levels of the independent variables are given in Table 2. A $2^{4}$ factorial CCD was developed by design expert package version 7.1 .6 with 8 axial points and 6 replicates at the center points leading to 30 runs. The variables were coded according to the following equation.

$$
x_{i}=\frac{X_{i}-X_{0}}{\Delta X}, \mathrm{i}=1,2,3, \ldots, \mathrm{k}
$$

Where $x_{i}$ is the dimensionless value of an independent variable, $X_{i}$ is the real value of an independent variable, $X_{0}$ is the value of $X_{i}$ at the center point and $\Delta X$ is the step change. A second-order polynomial model was used to fit the quadratic resulting in the equation, 


$$
\begin{aligned}
& Y=\beta_{0}+\beta_{1} x_{1}+\beta_{2} x_{2}+\beta_{3} x_{3}+\beta_{4} x_{4}+\beta_{5} x_{1}^{2} \\
& +\beta_{6} x_{2}^{2}+\beta_{7} x_{3}^{2}+\beta_{8} x_{4}^{2}+\beta_{9} x_{1} x_{2}+\beta_{10} x_{1} x_{3} \\
& +\beta_{11} x_{1} x_{4}+\beta_{12} x_{2} x_{3}+\beta_{13} x_{2} x_{4} \\
& +\beta_{14} x_{3} x_{4}
\end{aligned}
$$

Where $Y$ is the measured response (cellulase activity $(\mathrm{U} / \mathrm{ml})), x_{1}, x_{2}, x_{3}$ and $x_{4}$ are the coded independent input variables, $\beta_{0}$ is the intercept term, $\beta_{1}, \beta_{2}, \beta_{3}$ and $\beta_{4}$ are the coefficients showing the linear effects, $\beta_{5}, \beta_{6}, \beta_{7}$ and $\beta_{8}$ are the quadratic coefficients showing the squared effects and $\beta_{9}, \beta_{10}, \beta_{11}, \beta_{12}, \beta_{13}$, and $\beta_{14}$ are the cross product coefficients showing the interaction effects.

The optimum values of $\mathrm{CMC}, \mathrm{NH}_{4} \mathrm{NO}_{3}, \mathrm{KH}_{2} \mathrm{PO}_{4}$ and $\mathrm{pH}$ were obtained by solving the regression equation by Monte Carlo optimization (Conley, 1984). The goodness of fit of the model was evaluated by coefficient of determination $R^{2}$ and analysis of variance (ANOVA).

Table 2. Levels of the variables tested in CCD

\begin{tabular}{|c|c|c|c|c|c|c|}
\hline \multirow{2}{*}{ Variables \& symbol code } & \multicolumn{5}{|c|}{ Coded levels } \\
\cline { 3 - 7 } & -2 & -1 & 0 & +1 & +2 \\
\hline $\mathrm{CMC}\left(\mathrm{g} \mathrm{I}^{-1}\right)$ & $X_{1}$ & 0.40 & 0.8 & 1.20 & 1.60 & 2.00 \\
\hline $\begin{array}{c}\mathrm{NH}_{4} \mathrm{NO}_{3} \\
\left(\mathrm{mg} \mathrm{l}^{-1}\right)\end{array}$ & $X_{2}$ & 0.30 & 0.6 & 0.9 & 1.20 & 1.50 \\
\hline $\begin{array}{c}\mathrm{KH}_{2} \mathrm{PO}_{4} \\
\left(\mathrm{mg} \mathrm{l}^{-1}\right)\end{array}$ & $X_{3}$ & 0.25 & 0.5 & 0.75 & 1.00 & 1.25 \\
\hline $\mathrm{pH}$ & $X_{4}$ & 4.0 & 4.5 & 5.0 & 5.5 & 6.0 \\
\hline
\end{tabular}

Results and discussion

Visualization of zones of CMC hydrolysis by gel diffusion assay

CMC agar plates examined after gel diffusion assay produced zones of hydrolysis within 5 days. A. nidulans showed activity against CMC (zone of clearing diameter $1.3 \mathrm{~cm}$ ). CMC agar plated with $A$. nidulans, stained with $1 \%$ congo red and fixed with $\mathrm{NaOH}$. This enhanced the contrast between the halo and the background. Halo formation on CMC agar plates resulted from cleavage of $\mathrm{CMC}$ into fragments smaller than cellohexaose to which congo red did not bind.

Moreover, halos could result from cleavage of CMC into fragments small enough to be washed out of the plates during the staining procedure (Saczi \& Radford, 1986). In either case only endoglucanase activity would be expected to produce a zone of hydrolysis. The fungi used in this study exhibited strong cellulolytic activity which got confirmed by the production of zone of hydrolysis. Fig. 1 depicts the growth profile and activity of cellulase produced by $A$. nidulans. There was a significant increase in the biomass and cellulase activity $(4.91 \mathrm{U} / \mathrm{ml})$, which were at their peak on the $6^{\text {th }}$ day of incubation. The initial $\mathrm{pH}$ variation from 3 to 7 had significant effect on cellulase activity (Fig. 2a).

Cellulase activity was found to be predominant at $\mathrm{pH}$ value of 5 (Robson \& Chambliss, 1984; Zverlov et al., 1998). Earlier reports also suggested maximum Research article (CIndian Society for Education and Environment (iSee)
Vol. 3 No. 8 (Aug 2010)

ISSN: 0974- 6846

production of cellulase at this value of $\mathrm{pH}$ (Geeraerts \& Vandamme, 2008).

\section{Optimization by OFAT}

The experimental combinations for OFAT have been shown in Table 3. During SmF, carbon source was seen to act as major constituent for the synthesis of cellulase. The effect of different carbon sources on cellulase production has been shown in Fig. $2 \mathrm{~b}$. It was seen that carbon source that provided free glucose, did not aid cellulase production, whereas the source that provided complex carbon (CMC) aided in the production of cellulase. Glucose, being the easily assimilated carbon source supported growth without the need or with less need for producing cellulose (Niranjane et al., 2007). When used as carbon source, it was seen to provide maximum dry cell weight of $4.523 \mathrm{~g} / \mathrm{l}$ and cellulase activity of $4.32 \mathrm{U} / \mathrm{ml}$, whereas $\mathrm{CMC}$ supported maximum cellulase activity of $20.5 \mathrm{U} / \mathrm{ml}$ with dry cell weight of 3.412 $\mathrm{g} / \mathrm{l}$ after $5 \mathrm{~d}$ of incubator shaking.

Fig. 2c shows the effect of different nitrogen sources on cellulase activity. The organic nitrogen sources, yeast extract and peptone gave more biomass with least cellulase activity, whereas the inorganic nitrogen sources, $\mathrm{NH}_{4} \mathrm{NO}_{3}$ and Urea supported least biomass and higher cellulase activity. This may be attributed to the fact that complex substances like amino acids and vitamins in organic nitrogen sources could trigger the biomass production, thus making it unnecessary for the fungus to produce cellulase (Wen et al., 2005). Absence of these in the inorganic nitrogen sources instigated $A$. nidulans to make the most use of carbon source for cellulase production but with less increase in biomass. Maximum cellulase activity of $14.31 \mathrm{U} / \mathrm{ml}$ was observed when $\mathrm{NH}_{4} \mathrm{NO}_{3}$ was employed in the medium as the chief nitrogen source. The maximum activity of cellulase was obtained when the fungal strain was supplied with an optimum level of carbon and nitrogen source.

Table 3. OFAT design matrix with experimental values

\begin{tabular}{|c|c|c|c|c|c|c|c|c|c|}
\hline \multirow{2}{*}{ Run } & \multicolumn{4}{|c|}{ Component } & \multicolumn{3}{|c|}{ Medium component } & \multirow{2}{*}{ U/ml } \\
\cline { 2 - 8 } & $X_{1}$ & $X_{2}$ & $X_{3}$ & $X_{4}$ & $X_{1}$ & $X_{2}$ & $X_{3}$ & $X_{4}$ & \\
\hline 1 & $\mathrm{~A} 1$ & $\mathrm{~B} 1$ & $\mathrm{C} 1$ & $\mathrm{D} 1$ & $\mathrm{G}$ & $\mathrm{Y}$ & $\mathrm{CC}$ & 3 & 4.32 \\
\hline 2 & $\mathrm{~A} 2$ & $\mathrm{~B} 1$ & $\mathrm{C} 1$ & $\mathrm{D} 1$ & $\mathrm{~S}$ & $\mathrm{Y}$ & $\mathrm{CC}$ & 3 & 6.32 \\
\hline 3 & $\mathrm{~A} 3$ & $\mathrm{~B} 1$ & $\mathrm{C} 1$ & $\mathrm{D} 1$ & $\mathrm{C}$ & $\mathrm{Y}$ & $\mathrm{CC}$ & 3 & 20.5 \\
\hline 4 & $\mathrm{~A} 4$ & $\mathrm{~B} 1$ & $\mathrm{C} 1$ & $\mathrm{D} 1$ & $\mathrm{C}$ & $\mathrm{Y}$ & $\mathrm{CC}$ & 3 & 5.41 \\
\hline 5 & $\mathrm{~A} 1$ & $\mathrm{~B} 1$ & $\mathrm{C} 1$ & $\mathrm{D} 1$ & $\mathrm{G}$ & $\mathrm{Y}$ & $\mathrm{CC}$ & 3 & 3.21 \\
\hline 6 & $\mathrm{~A} 1$ & $\mathrm{~B} 2$ & $\mathrm{C} 1$ & $\mathrm{D} 1$ & $\mathrm{G}$ & $\mathrm{A}$ & $\mathrm{CC}$ & 3 & 14.31 \\
\hline 7 & $\mathrm{~A} 1$ & $\mathrm{~B} 3$ & $\mathrm{C} 1$ & $\mathrm{D} 1$ & $\mathrm{G}$ & $\mathrm{P}$ & $\mathrm{CC}$ & 3 & 2.14 \\
\hline 8 & $\mathrm{~A} 1$ & $\mathrm{~B} 4$ & $\mathrm{C} 1$ & $\mathrm{D} 1$ & $\mathrm{G}$ & $\mathrm{U}$ & $\mathrm{CC}$ & 3 & 12.41 \\
\hline 9 & $\mathrm{~A} 1$ & $\mathrm{~B} 1$ & $\mathrm{C} 1$ & $\mathrm{D} 1$ & $\mathrm{G}$ & $\mathrm{Y}$ & $\mathrm{CC}$ & 3 & 1.03 \\
\hline 10 & $\mathrm{~A} 1$ & $\mathrm{~B} 1$ & $\mathrm{C} 2$ & $\mathrm{D} 1$ & $\mathrm{G}$ & $\mathrm{Y}$ & $\mathrm{K}$ & 3 & 5.92 \\
\hline 11 & $\mathrm{~A} 1$ & $\mathrm{~B} 1$ & $\mathrm{C} 3$ & $\mathrm{D} 1$ & $\mathrm{G}$ & $\mathrm{Y}$ & $\mathrm{M}$ & 3 & 4.91 \\
\hline 12 & $\mathrm{~A} 1$ & $\mathrm{~B} 1$ & $\mathrm{C} 4$ & $\mathrm{D} 1$ & $\mathrm{G}$ & $\mathrm{Y}$ & $\mathrm{T}$ & 3 & 4.51 \\
\hline 13 & $\mathrm{~A} 1$ & $\mathrm{~B} 1$ & $\mathrm{C} 1$ & $\mathrm{D} 1$ & $\mathrm{G}$ & $\mathrm{Y}$ & $\mathrm{CC}$ & 3 & 2.13 \\
\hline 14 & $\mathrm{~A} 1$ & $\mathrm{~B} 1$ & $\mathrm{C} 1$ & $\mathrm{D} 2$ & $\mathrm{G}$ & $\mathrm{Y}$ & $\mathrm{CC}$ & 4 & 3.14 \\
\hline 15 & $\mathrm{~A} 1$ & $\mathrm{~B} 1$ & $\mathrm{C} 1$ & $\mathrm{D} 3$ & $\mathrm{G}$ & $\mathrm{Y}$ & $\mathrm{CC}$ & 5 & 5.92 \\
\hline 16 & $\mathrm{~A} 1$ & $\mathrm{~B} 1$ & $\mathrm{C} 1$ & $\mathrm{D} 4$ & $\mathrm{G}$ & $\mathrm{Y}$ & $\mathrm{CC}$ & 6 & 4.01 \\
\hline
\end{tabular}


Fig. 1 Time course of dry cell weight ( $\Delta$ ) \& cellulase activity (A).

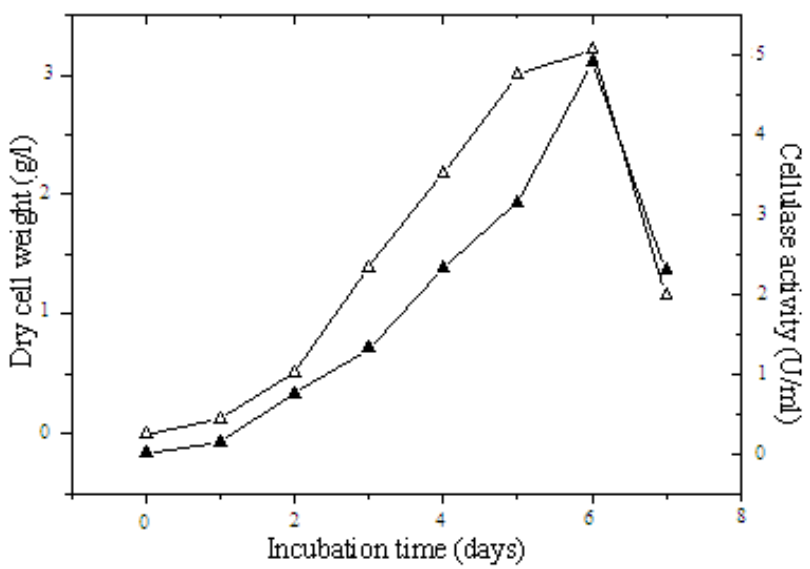

Fig.2.b.Effect of carbon source on dry cell weight $(\square)$ and Cellulase activity $(\square)$

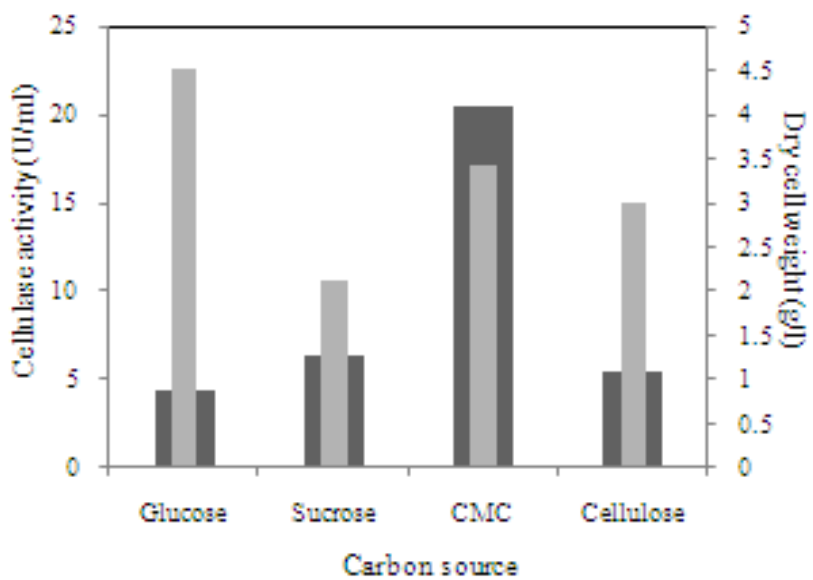

Fig.2.d. Effect of Mineral salts on dry cell weight $(\square)$ and cellulase activity $(\square)$

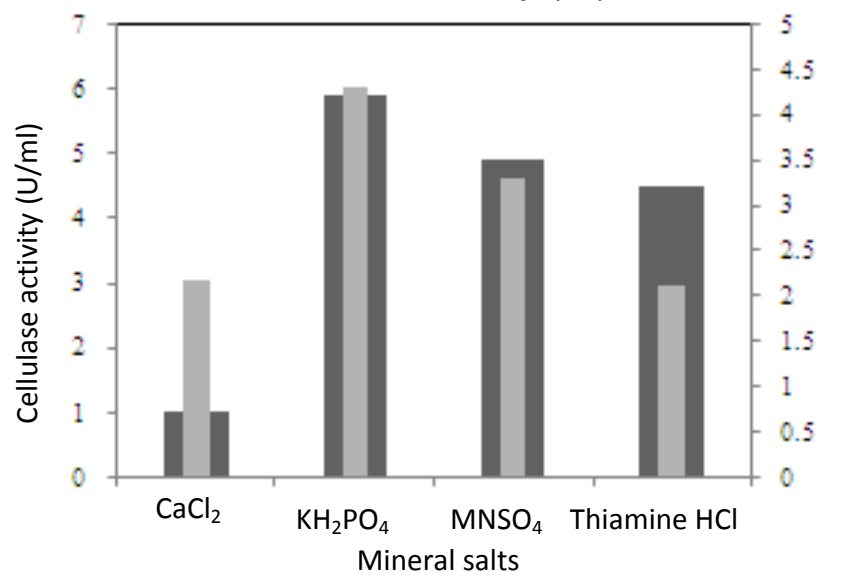

Research article

(C)Indian Society for Education and Environment (iSee)
Vol. 3 No. 8 (Aug 2010)

ISSN: 0974- 6846

Fig.2.a.Effect of $\mathrm{pH}$ on dry cell weight $(\square)$ and cellulase activity $(\square)$ of $A$. nidulans grown on Initial medium

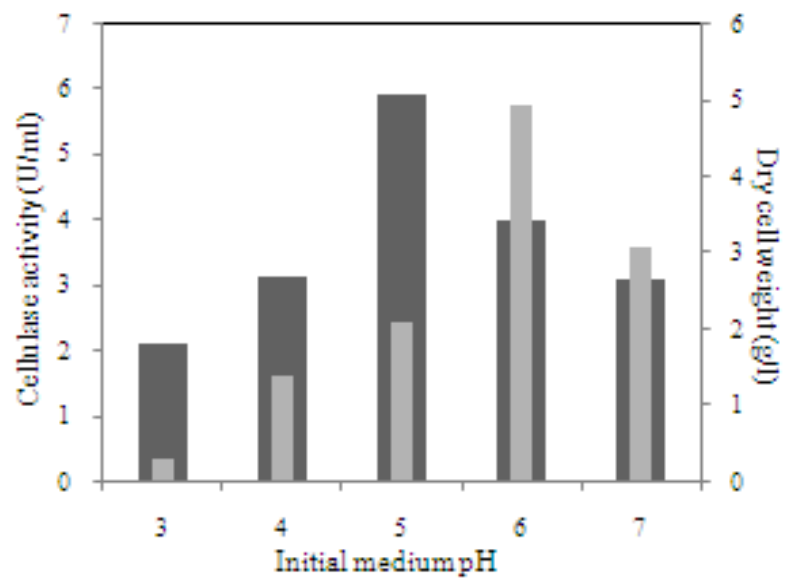

Fig.2.c. Effect of Nitrogen sources on dry cell weight $(\square)$ and Cellulase activity $(\square)$

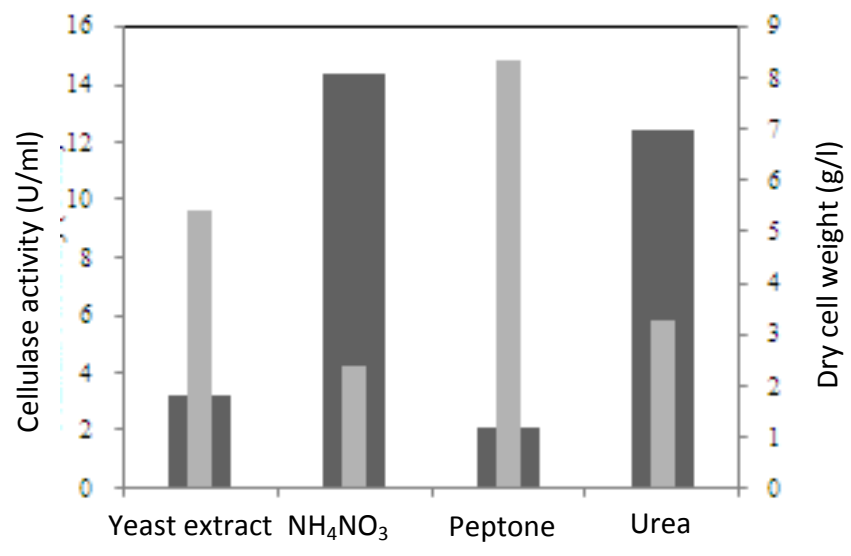

Nitrogen source

Fig.3.Residuals versus predicted cellulase activity

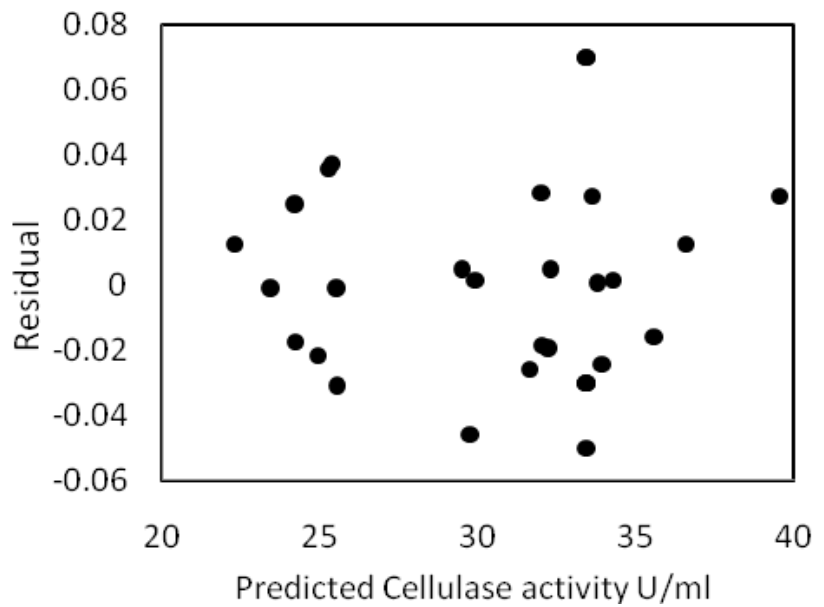

"Cellulase"

Anuradha \& Valli Indian J.Sci.Technol. 
Indian Journal of Science and Technology

Table 4. PB design matrix with experimental values for cellulase activity

\begin{tabular}{|c|c|c|c|c|c|c|c|c|}
\hline Run & \multicolumn{7}{|c|}{ Variables } & \multirow{2}{*}{$(\mathrm{U} / \mathrm{ml})$} \\
\hline & $A$ & $B$ & $C$ & $D$ & $E$ & $F$ & $G$ & \\
\hline 1 & +1 & +1 & +1 & -1 & +1 & -1 & +1 & 40.32 \\
\hline 2 & -1 & +1 & +1 & +1 & -1 & +1 & -1 & 10.31 \\
\hline 3 & -1 & -1 & +1 & +1 & +1 & -1 & +1 & 29.18 \\
\hline 4 & +1 & -1 & -1 & +1 & +1 & +1 & -1 & 17.21 \\
\hline 5 & -1 & +1 & -1 & -1 & +1 & +1 & +1 & 17.10 \\
\hline 6 & +1 & -1 & +1 & -1 & -1 & +1 & +1 & 35.61 \\
\hline 7 & +1 & +1 & -1 & +1 & -1 & -1 & +1 & 20.19 \\
\hline 8 & -1 & -1 & -1 & -1 & -1 & -1 & -1 & 11.12 \\
\hline
\end{tabular}

Fig. $2 \mathrm{~d}$ shows the effect of different mineral salts on the activity of cellulase. $\mathrm{KH}_{2} \mathrm{PO}_{4}, \mathrm{MnSO}_{4} \cdot \mathrm{H}_{2} \mathrm{O}$ and thiamine hydrochloride were seen to support the maximum activity of cellulase compared to $\mathrm{CaCl}_{2} \cdot 2 \mathrm{H}_{2} \mathrm{O}$.

\section{Optimization by PBSD}

The second optimization was done by using 8 run PBSD to identify the significant factors affecting cellulase activity of $A$. nidulans. The experimental design for screening the medium components has been shown in Table 4. The experimental data for cellulase activity in Plackett Burmann trials were also listed. The results showed a wide variation from $11.12 \mathrm{U} / \mathrm{ml}$ to $40.32 \mathrm{U} / \mathrm{ml}$, which reflected the importance of medium optimization for higher cellulase activities.

According to the resulting effects of the 7 variables on cellulase activity, associated significant levels have been shown in Table 5. CMC (G) showed large effect followed by $\mathrm{NH}_{4} \mathrm{NO}_{3}$ (C) and $\mathrm{KH}_{2} \mathrm{PO}_{4}$ (A). Thiamine $\mathrm{HCl}(E)$ showed least effect followed by Urea $(B)$.It could be seen with the high concentration of $\mathrm{CMC}$ and with least concentration of urea, the cellulase activity of the enzyme produced by the fungus was predominating, provided, $\mathrm{NH}_{4} \mathrm{NO}_{3}$ and $\mathrm{KH}_{2} \mathrm{PO}_{4}$ were held at high concentration and $\mathrm{pH}$ was maintained at $5 . \mathrm{MnSO}_{4} \cdot \mathrm{H}_{2} \mathrm{O}(D)$ and Peptone $(F)$ are dummy variables.

Table 5. PBSD results and significant levels

\begin{tabular}{|c|c|c|c|c|c|c|c|}
\hline Trials & $A$ & $B$ & $C$ & $D$ & $E$ & $F$ & $G$ \\
\hline$\sum \mathrm{H}$ & 113.3 & 87.9 & 115.4 & 76.89 & 103.8 & 80.23 & 142.4 \\
\hline$\sum \mathrm{L}$ & 67.71 & 93.1 & 65.62 & 104.2 & 77.23 & 100.8 & 38.64 \\
\hline$\sum \mathrm{H}-\sum \mathrm{L}$ & 45.62 & -5.2 & 49.8 & -27.3 & 26.58 & -20.6 & 103.8 \\
\hline Effect & 11.40 & 1.3 & 12.45 & -6.82 & 6.645 & -5.15 & 25.94 \\
\hline $\mathrm{MS}$ & 260.2 & 3.38 & 310.0 & 92.88 & 88.31 & 52.94 & 1345.8 \\
\hline $\mathrm{F}$ & 2.872 & 0.04 & 3.422 & 1.025 & 0.975 & 0.584 & 14.86 \\
\hline \multicolumn{7}{c|}{ MS-mean square; EMS-error mean square $=90.60$}
\end{tabular}

\section{Optimisation by RSM}

The effect of 4 variables on cellulase activity was studied by the third optimization technique, the response surface methodology.

Research article

CIndian Society for Education and Environment (iSee)
"Cellulase" http://www.indjst.org
Vol. 3 No. 8 (Aug 2010)

ISSN: 0974- 6846

Fig.4(a).Response surface plot showing the effect of CMC and $\mathrm{NH}_{4} \mathrm{NO}_{3}$ on cellulase activity of A. nidulans $\left(\mathrm{KH}_{2} \mathrm{PO}_{4} 0.75 \mathrm{mg} / \mathrm{l}\right.$ and $\mathrm{pH}$ 5.0)

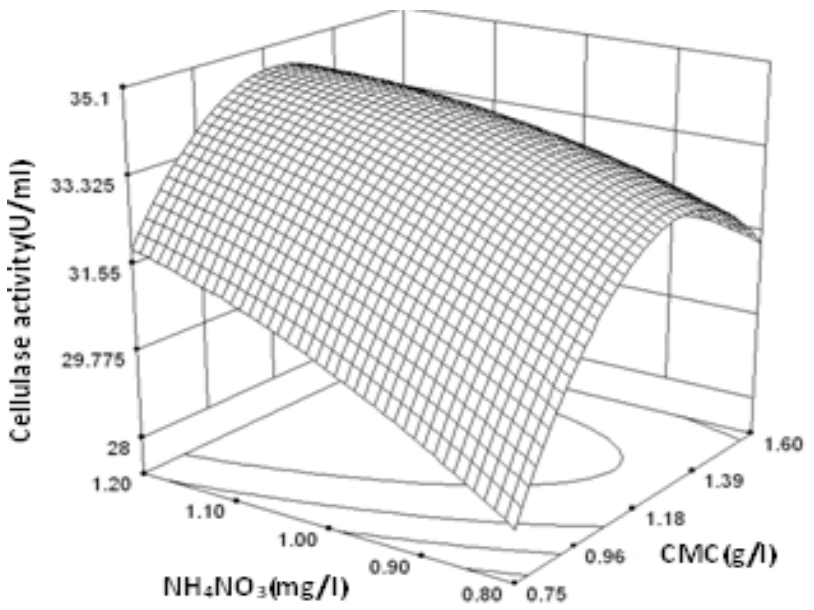

Fig.4 (b). Response surface plot showing the effect of $C M C$ and $\mathrm{KH}_{2} \mathrm{PO}_{4}$ on cellulase activity by A. nidulans $\left(\mathrm{NH}_{4} \mathrm{NO}_{3} 0.90 \mathrm{mg} / \mathrm{l}\right.$ and $\mathrm{pH}$ 5.0)

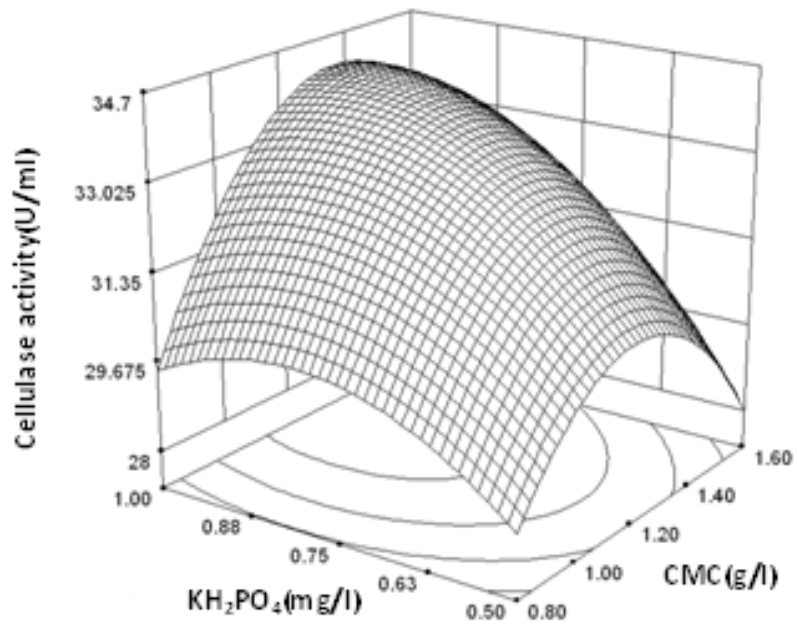

Fig.4(c). Response surface plot showing the effect of $\mathrm{NH}_{4} \mathrm{NO}_{3}$ and $\mathrm{KH}_{2} \mathrm{PO}_{4}$ on cellulase activity by A. nidulans(CMC 1.2g/l and $\mathrm{pH}$ 5.0)

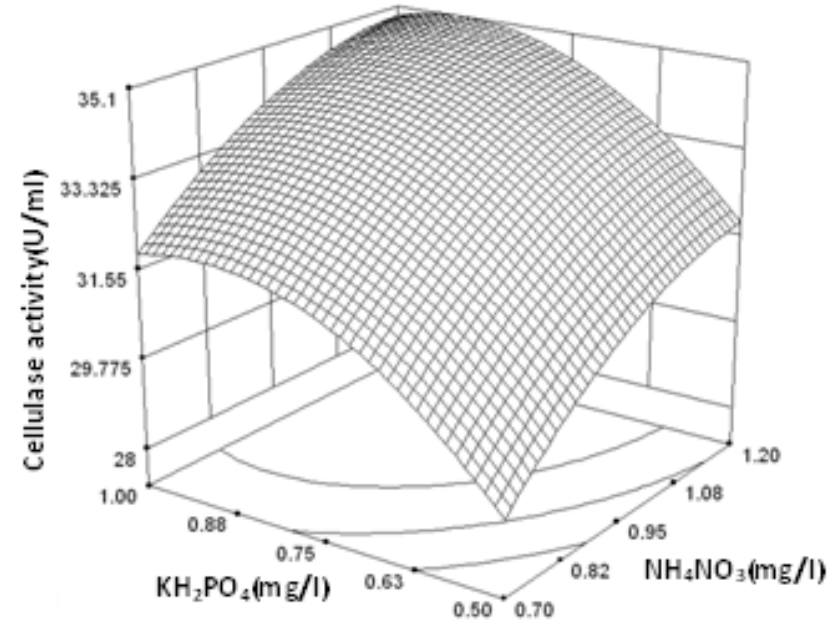

Anuradha \& Valli Indian J.Sci.Technol. 
$Y_{i}=33.43+0.80 x_{1}+2.17 x_{2}+1.57 x_{3}+0.99 x_{4}$

$-2.38 x_{1}^{2}-0.96 x_{2}^{2}-1.23 x_{3}^{2}+1.04 x_{4}^{2}$

$-1.08 x_{1} x_{2}+1.02 x_{1} x_{3}+1.54 x_{1} x_{4}$

$-0.065 x_{2} x_{3}+1.13 x_{2} x_{4}$

$-1.37 x_{3} x_{4}$

Table 6 gives the CCD matrix with experimental and predicted values for cellulase activity. The regression equation showed the cellulase activity as an empirical function in terms of coded factors, where $Y_{i}$ is the predicted cellulase activity in $\mathrm{U} / \mathrm{ml}$. ANOVA for response surface quadratic model gave $F$ value $=23338.52$, with $p$ values of all the coefficients $(p<0.0001)$, implying the significance of the model. The coefficient of variation of the model was ( $C . V=0.14 \%)$. The goodness of fit of the model was examined by determination coefficient $\left(R^{2}=0.999\right)$ which implied that sample variation of more

Table 6. Central composite design matrix in coded terms showing the experimental and predicted values for cellulase activity

\begin{tabular}{|c|c|c|c|c|c|c|}
\hline \multirow[t]{2}{*}{ Trials } & \multicolumn{4}{|c|}{$\begin{array}{l}\text { Experimental } \\
\text { values }\end{array}$} & \multicolumn{2}{|c|}{$\begin{array}{c}\text { Cellulase activity } \\
(\mathrm{U} / \mathrm{ml})\end{array}$} \\
\hline & $X_{1}$ & $X_{2}$ & $x_{3}$ & $x_{4}$ & Experimental * & Predicted \\
\hline 1 & -1 & -1 & -1 & -1 & 25.50 & 25.53 \\
\hline 2 & 1 & -1 & -1 & -1 & 24.20 & 24.17 \\
\hline 3 & -1 & 1 & -1 & -1 & 29.90 & 29.89 \\
\hline 4 & 1 & 1 & -1 & -1 & 24.20 & 24.21 \\
\hline 5 & -1 & -1 & 1 & -1 & 29.51 & 29.50 \\
\hline 6 & 1 & -1 & 1 & -1 & 32.20 & 32.21 \\
\hline 7 & -1 & 1 & 1 & -1 & 33.64 & 33.61 \\
\hline 8 & 1 & 1 & 1 & -1 & 32.03 & 32.00 \\
\hline 9 & -1 & -1 & -1 & 1 & 24.90 & 24.92 \\
\hline 10 & 1 & -1 & -1 & 1 & 29.70 & 29.74 \\
\hline 11 & -1 & 1 & -1 & 1 & 33.80 & 33.79 \\
\hline 12 & 1 & 1 & -1 & 1 & 34.30 & 34.29 \\
\hline 13 & -1 & -1 & 1 & 1 & 23.40 & 23.40 \\
\hline 14 & 1 & -1 & 1 & 1 & 32.30 & 32.29 \\
\hline 15 & -1 & 1 & 1 & 1 & 32.00 & 32.01 \\
\hline 16 & 1 & 1 & 1 & 1 & 36.60 & 36.58 \\
\hline 17 & -2 & 0 & 0 & 0 & 22.30 & 22.28 \\
\hline 18 & 2 & 0 & 0 & 0 & 25.50 & 25.50 \\
\hline 19 & 0 & -2 & 0 & 0 & 25.30 & 25.26 \\
\hline 20 & 0 & 2 & 0 & 0 & 33.90 & 33.92 \\
\hline 21 & 0 & 0 & -2 & 0 & 25.40 & 25.36 \\
\hline 22 & 0 & 0 & 2 & 0 & 31.60 & 31.62 \\
\hline 23 & 0 & 0 & 0 & -2 & 35.57 & 35.58 \\
\hline 24 & 0 & 0 & 0 & 2 & 39.59 & 39.56 \\
\hline 25 & 0 & 0 & 0 & 0 & 33.38 & 33.43 \\
\hline 26 & 0 & 0 & 0 & 0 & 33.40 & 33.43 \\
\hline 27 & 0 & 0 & 0 & 0 & 33.50 & 33.43 \\
\hline 28 & 0 & 0 & 0 & 0 & 33.40 & 33.43 \\
\hline 29 & 0 & 0 & 0 & 0 & 33.50 & 33.43 \\
\hline 30 & 0 & 0 & 0 & 0 & 33.40 & 33.43 \\
\hline
\end{tabular}

*The observed values of cellulase activity were the means of triplicates
Vol. 3 No. 8 (Aug 2010)

ISSN: 0974- 6846

than $99.9 \%$ was attributed to the variables and only $0.1 \%$ of total variance could not be explained by the model (Haaland,1989). The adjusted determination coefficient (Adj $R^{2}=0.999$ ) was also satisfactory to confirm the significance of the model. The "Pred R-Squared" of 0.9998 was in reasonable agreement with the "Adj RSquared" of 0.9999. Adeq precision measured the signal to noise ratio. A ratio greater than 4 is desirable. The ratio of 575.478 obtained in this model indicated an adequate signal which could be used to navigate the design space. The results of the response surface quadratic model in the form of analysis of variance (ANOVA) with significance of each coefficient, determined by student's $\mathrm{t}$ - test and $\mathrm{p}$ - value are listed in Table 7 . The larger the magnitude of the $\mathrm{t}$ in t-test and smaller the $\mathrm{p}$-value, the more significant is the corresponding coefficient. $\mathrm{KH}_{2} \mathrm{PO}_{4}$ has a strong positive linear effect on the response $(p<<$ 1.4E-25). $\quad \mathrm{NH}_{4} \mathrm{NO}_{3}$ also showed significant effect. Significant interaction was seen between $\mathrm{CMC}$ with $\mathrm{KH}_{2} \mathrm{PO}_{4}$ and $\mathrm{pH}$ of the medium and between $\mathrm{NH}_{4} \mathrm{NO}_{3}$ and $\mathrm{pH}$ of the medium (Elisashvili \& Penninckx, 2008). The model predicted maximum cellulase activity of $39.56 \mathrm{U} / \mathrm{ml}$ with $1.2 \mathrm{~g} / \mathrm{l} \mathrm{CMC}, 0.9 \mathrm{mg} / \mathrm{l} \mathrm{NH} \mathrm{NO}_{3}$ and $0.9 \mathrm{mg} / \mathrm{K} \mathrm{KH}_{2} \mathrm{PO}_{4}$ at pH 5 (Adsul et al., 2007; Martinsa et al., 2008). Fig. 3 shows the variation of residuals against the predicted cellulase activity. Response surface contours plots and three dimensional graphs are employed to understand the relationship between the response and experimental levels of each variable.

These plots also showed the type of interaction between test variables and helped to obtain the optimum conditions (Haaland, 1989). Fig. 4a shows the cellulase activity as a result of interaction between CMC and ammonium nitrate with potassium dihydrogen phosphate and $\mathrm{pH}$ maintained at $0.75 \mathrm{mg} / \mathrm{l}$ and 5 respectively. A high carbon source and low nitrogen source was seen to enhance the activity of cellulase produced by the organism. Interaction between CMC and potassium dihydrogen phosphate at constant values of Ammonium nitrate $0.9 \mathrm{mg} / \mathrm{l}$ and pH 5.0 has been shown in Fig. 4b.

The cellulase activity was seen to increase with an increase in the concentration of CMC upto $1.2 \mathrm{~g} / \mathrm{l}$ after which it started to decrease significantly. Similar trend was observed with $\mathrm{KH}_{2} \mathrm{PO}_{4}$ whose concentration of 0.75 $\mathrm{mg} / \mathrm{l}$ was seen to provide a maximum cellulase activity. Fig. 4c shows the interaction between $\mathrm{NH}_{4} \mathrm{NO}_{3}$ and $\mathrm{KH}_{2} \mathrm{PO}_{4}$. The response surface clearly indicated the poor performance of the fungi in the production of cellulase with significant activity at low values of this nitrogen source and mineral salt.

Final optimized conditions are obtained by solving inverse matrix from eqn. (3) and through statistical analysis of the constraints. By both means the optimum values of the tested variables in uncoded (natural) units obtained were CMC $1.2 \mathrm{~g} / \mathrm{l}, \mathrm{NH}_{4} \mathrm{NO}_{3} 0.9 \mathrm{mg} / \mathrm{l}, \mathrm{KH}_{2} \mathrm{PO}_{4}$ $0.75 \mathrm{mg} / \mathrm{l}$ at $\mathrm{pH}$ 5. At these optimized conditions the model predicted $39.56 \mathrm{U} / \mathrm{ml}$ of cellulase activity. The
Research article

CIndian Society for Education and Environment (iSee)
"Cellulase"

http://www.indjst.org
Anuradha \& Valli Indian J.Sci.Technol. 
subsequent experiments with optimized medium were observed to yield consistent results with prediction. Cellulase activity obtained by optimizing the medium contents was found to be significantly affected by the interaction of $A$. nidulans with the designed medium (Jorgensen et al., 2005). The present study using one factor at a time methodology, Plackett Burmann methodology and response surface methodology enabled us to find the optimum levels of the ingredients of the medium designed to produce cellulase of increasing activity.

\section{References}

1. Adsul MG, Bastawde KB, Varma AJ and Gokhale DV (2007) Strain improvement of Penicillium janthinellum NCIM1171 for increased cellulase production. Biores. Technol. 98, 1467-1473.

2. Amani MD, El Ahwany and Youssef AS (2007) Xylanase production by Bacillus pumilus: Optimization by statistical and immobilization methods. Res. J. Agri. Biol. Sci. 3(6), 727-732.

3. Berekaa MM, Abdel-Fattah YR, El-Sayed SM, Borai AMEL and El Aassar SA (2006) Optimization of culture conditions for production of polyamide biopolymer (Polyglutamate) by Bacillus sp.

Table 7. Analysis of variance (ANOVA), regression coefficient estimate and test of significance for cellulase activity (response surface quadratic model)

\begin{tabular}{|c|c|c|c|c|c|c|c|}
\hline Factor & $\begin{array}{c}\text { Sum of } \\
\text { squares }\end{array}$ & $\begin{array}{c}\text { Mean } \\
\text { squares }\end{array}$ & $\begin{array}{c}\text { Coefficient } \\
\text { estimate }\end{array}$ & d.f & $\begin{array}{c}\text { Computed } \\
\text { t-value }\end{array}$ & F-value & P-value \\
\hline Intercept & 588.86 & 42.06 & 33.43 & 14 & 107.421 & 23338.52 & $4.539 \mathrm{E}-23$ \\
\hline $\mathrm{X}_{1}$ & 15.46 & 15.49 & 0.80 & 1 & -1.209 & 8593.98 & 0.2453 \\
\hline $\mathrm{X}_{2}$ & 112.49 & 112.49 & 2.17 & 1 & 0.657 & 62419.27 & 0.5207 \\
\hline $\mathrm{X}_{3}$ & 58.84 & 58.84 & 1.57 & 1 & 158.256 & 32650.81 & $1.365 \mathrm{E}-25$ \\
\hline $\mathrm{X}_{4}$ & 23.72 & 23.72 & 0.99 & 1 & -137.974 & 13161.98 & $1.089 \mathrm{E}-24$ \\
\hline $\mathrm{X}_{1}{ }^{*} \mathrm{X}_{2}$ & 18.71 & 18.71 & -1.08 & 1 & -294.100 & 10379.20 & $1.257 \mathrm{E}-29$ \\
\hline $\mathrm{X}_{1}{ }^{*} \mathrm{X}_{3}$ & 16.56 & 16.56 & 1.02 & 1 & -118.303 & 9191.37 & $1.069 \mathrm{E}-23$ \\
\hline $\mathrm{X}_{1}{ }^{*} \mathrm{X}_{4}$ & 38.19 & 38.19 & 1.54 & 1 & -152.229 & 21191.84 & $2.442 \mathrm{E}-25$ \\
\hline $\mathrm{X}_{2}{ }^{*} \mathrm{X}_{3}$ & 0.068 & 0.068 & -0.065 & 1 & 127.812 & 37.51 & $3.357 \mathrm{E}-24$ \\
\hline $\mathrm{X}_{2}{ }^{*} \mathrm{X}_{4}$ & 20.34 & 20.34 & 1.13 & 1 & -101.878 & 11286.12 & $1.004 \mathrm{E}-22$ \\
\hline $\mathrm{X}_{3}{ }^{*} \mathrm{X}_{4}$ & 30.20 & 30.20 & -1.37 & 1 & 95.871 & 16754.33 & $2.495 \mathrm{E}-22$ \\
\hline $\mathrm{X}_{1}{ }^{2}$ & 155.88 & 155.88 & -2.38 & 1 & 145.574 & 86495.23 & $4.774 \mathrm{E}-25$ \\
\hline $\mathrm{X}_{2}{ }^{2}$ & 25.22 & 25.22 & -0.96 & 1 & -6.124 & 13995.69 & $1.945 \mathrm{E}-05$ \\
\hline $\mathrm{X}_{3}{ }^{2}$ & 41.76 & 41.76 & -1.23 & 1 & 106.236 & 23173.72 & $5.360 \mathrm{E}-23$ \\
\hline $\mathrm{X}_{4}{ }^{2}$ & 29.44 & 29.44 & 1.04 & 1 & -129.438 & 16336.13 & $2.777 \mathrm{E}-24$ \\
\hline Residual & 0.027 & $1.802 \mathrm{E}-$ & & 15 & & & \\
\hline
\end{tabular}

\section{Conclusion}

The present study demonstrates the usage of combination optimization methodology to produce cellulase with significant activity. In this investigation one factor at a time methodology, Plackett Burmann methodology and response surface methodology based on four-factor-five-level central composite design (CCD) was used to solve the problem. The results presented here confirm the feasibility of medium optimization and cultivation conditions to improve cellulase activity. Optimization of process parameters resulted in increase in cellulase activity from $4.91 \mathrm{U} / \mathrm{ml}$ to $39.56 \mathrm{U} / \mathrm{ml}$ by $A$. nidulans. To the best of our knowledge, this magnitude of enzyme activity produced by $A$. nidulans has not been reported so far. A continued multidisciplinary research on the basic and applied aspects was essential to meet the growing demand for cellulase. This work on cellulase production would be continued with experiments on purification and batch fermentations aiming at higher yields. The data obtained in the present and future studies would be used to model the cellulase production by $A$. nidulans.
8. Chen M, Zhao J and Xia L (2008) Enzymatic hydrolysis of maize straw polysaccharides for the production of reducing sugars. Carbohydrate Polym. 71, 411- 415.

9. Conley WC (1984) Computer optimization techniques. Petrocelli books, Princeton, NJ, 84(24), 147-163.

10. Elisashvili $V$ and Penninckx M (2008) Lentinus edodes and Pleurotus species lignocellulolytic enzymes activity in submerged and solid-state fermentation of lignocellulosic wastes of different composition. Biores. Technol. 99,457-462.

11. Geeraerts HAM and Vandamme EJ (2008) Cellulolytic properties of Chaetomium crispatum. J. Chem. Technol. Biotechnol. 33(2), 107-113.

12. Ghanem NB, Yusef HH and Mahrouse HK (2000) Production of Aspergillus terreus xylanase in solidstate cultures: application of the Plackett-Burmann experimental design to evaluate nutritional requirement. Biores. Technol. 73(2), 113-121.

13. Ghose TK (1987) Measurement of cellulase activities. Pure Appl. Chem. 59, 257-268.

14. Gommers FJ, Henrissat B, Davis EL, Helder J, Schots $A$ and Bakker $J(1998)$ Endogenous cellulases in animals:isolation of $\beta-1,4$-endoglucanase genes from
Research article

CIndian Society for Education and Environment (iSee)
"Cellulase"

http://www.indjst.org
Anuradha \& Valli

Indian J.Sci.Technol. 
two species of plant-parasitic cyst nematodes. Proc. 28. Tomme P, Warren, RAJ and Gilkes NR (1995) Natl. Acad. Sci. USA. 95, 4906-4911.

15. Guangrong $H$, Dehui D, Weilian $H$ and Jiaxin J (2008) Optimization of medium composition for thermostable 29. protease production by Bacillus sp. HS08 with a statistical method. Afri. J. Biotechnol. 7(8), 1115-1122.

16. Haaland PD (1989) Experimental design in Biotechnology, New York: Marcel Dekker; separating signals from the noise, 61-83.

Cellulose hydrolysis by bacteria and fungi. $A d v$. Microbiol. Physiol. 37, 1-81.

29. Watanabe H, Nakamura M, Tokuda G, Yamaoka I, Scrivener AM and Noda $H$ (1997) Site of secretion and properties of endogenous endo- $\beta$-1,4-glucanase component from Reticulitermes speratus (Kolbe), a Japanese subterranean termite. Insect Biochem. Mol. Biol. 27, 305-313.

17. Jorgensen $H$, Morkeberg A, Krogh KBR and Olsson L 30. Watanabe H, Noda H, Tokuda G and Lo N (1998) A (2005) Production of cellulases and hemicellulases by Penicillium species: effect of substrate and evaluation of cellulase adsorption by capillary electrophoresis, Enz. Microbial Technol. 36, 42-48. cellulase gene of termite origin. Nature. 394, 330-331.

31. Wen Z, Liao W and Chen S (2005) Production of cellulase by Trichoderma reesei from dairy manure. Biores. Technol. 96, 491-499.

18. Kim KC, Yoo SS, Oh YA and Kim SJ (2003) Isolation 32. Yi JC, Sandra JC, John AB and Shu TC (1999) and characteristics of $T$. harzianum FJ1 producing cellulases and xylanase, J. Microbial. Biotechnol.13, 18.

19. Lee SM and Koo YM (2001) Pilot-scale production of cellulase using $T$. reesei rut C-30 in fed-batch mode. $J$. Microbial Biotechnol. 11, 229-233.

20. Martinsa LF, Kolling D, Camassolab M, Dillon AJP and Ramos LP (2008) Comparison of Penicillium echinulatum and Trichoderma reesei cellulases in relation to their activity against various cellulosic substrates, Biores. Technol. 99, 1417-1424.

21. Moriya S, Ohkuma M and Kudo T (1998) Phylogenetic position of symbiotic protest Dinemympha exilis in the hindgut of the termite Reticulitermes speratus inferred from the protein phylogeny of elongation factor 1a. Gene. 210, 221-227.

22. Niranjane AP, Madhou P, Stevenson TW (2007) The effect of carbohydrate carbon sources on the production of cellulase by Phlebia gigantean. Enz. Microbial Technol. 40, 1464-1468.

23. Plackett RL and Burman JP (1946) The design of optimum multifactorial experiments. Biometrika. 33(4), 305-325.

24. Robson LM and Chambliss GH (1984) Characterization of the cellulolytic activity of a Bacillus isolate, Appl. Environ. Microbiol. 47(5), 1039-1046.

25. Saczi A and Radford A (1986) Detection of cellulolytic fungi by using congo red as an indicator: a comparative study with the dinitro salicyclic acid reagent method. J. Appl. Bacteriol. 61, 559-562.

26. Skowronek M and Fiedurek J (2004) Optimisation of Inulinase Production by Aspergillus niger. Food Technol. Biotechnol. 42(3), 141-146.

27. Smant G, Stokkermans JPWG, Yan Y, De Boer JM, Baum TJ, Wang X, Hussey RS, Tokuda G, Watanabe $\mathrm{H}$, Matsumoto T and Noda $\mathrm{H}$ (1997) Cellulose digestion in the wood-eating higher termite, Nasutitermes takasagoensis (Shiraki):distribution of cellulases and properties of endo- $\beta-1,4$-glucanase, Zool. Sci. 14, 8393. Production and distribution of endoglucanase, cellobio hydrolase and $\beta$-glucosidase components of the cellulolytic system of Volvariella volvacea, the edible straw mushroom. Appl. Environ. Microbiol. 65, 553-559.

33. Yokoe $Y$ and Yasumasu I (1964) The distribution of cellulase in invertebrates. Comp. Biochem. Physiol.13, 323-338.

34. Zverlov V, Mahr IS, Riedel $\mathrm{K}$ and Bronnenmeier $\mathrm{K}$ (1998) Properties and gene structure of bifunctional cellulolytic enzyme (CelA) from the extreme thermophile 'Anaerocellum thermophilum ' with separate glycosyl hydrolase family 9 and 48 catalytic domains. Microbiol. 144, 457-465. 